\title{
Head bobbing due to succinic semialdehyde dehydrogenase deficiency
}

回

Figure Magnetic resonance imaging
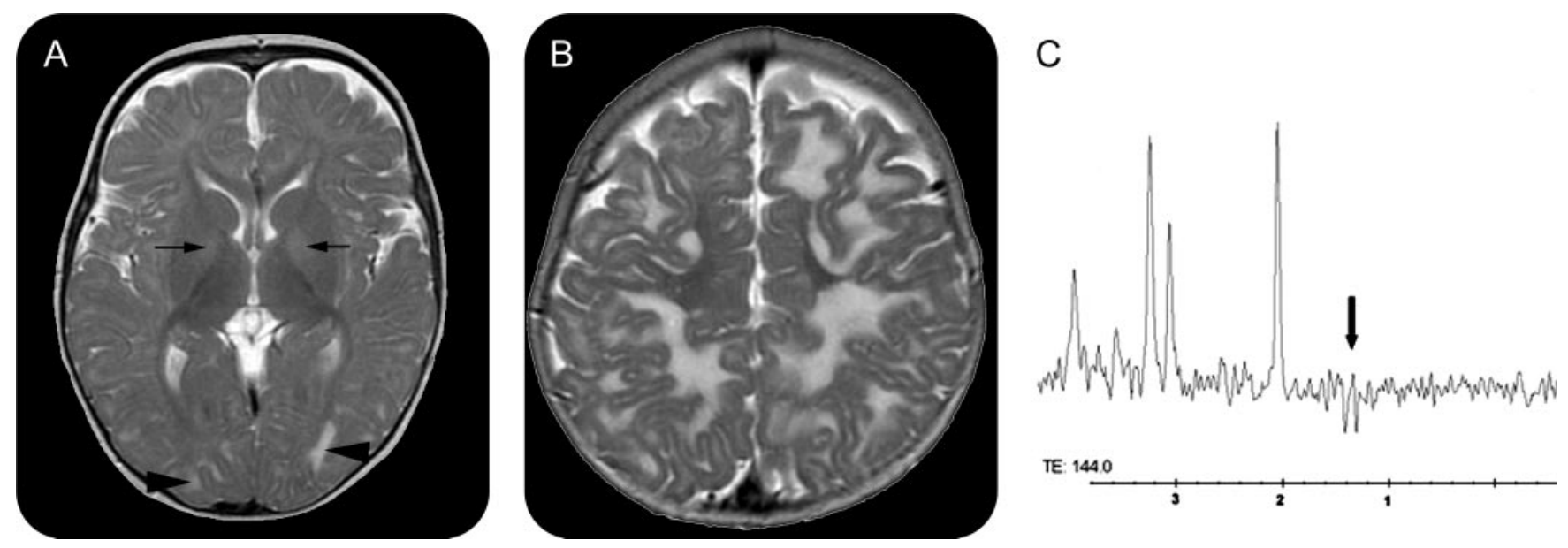

(A) Axial T2 MRI at level of basal ganglia shows abnormal high signal in the globus pallidus bilaterally (arrows). Abnormal high signal is also seen in the white matter posteriorly (arrowheads). (B) Axial T2 MRI above the level of the ventricles shows diffuse abnormal high signal in the white matter. (C) Magnetic resonance spectroscopy at long echo time $(T E=144)$ centered over left thalamus and basal ganglia shows inverted double peak at 1.3 ppm characteristic of lactate.

A 9-month-old boy had a short history of "yes-yes" head bobbing (video on the Neurology ${ }^{\circledR}$ Web site at www. neurology.org). Mild global delay prompted investigation. Imaging (figure, A-C), biochemical, and molecular findings (table e-1) were consistent with succinic semialdehyde dehydrogenase (SSADH) deficiency.

SSADH deficiency, a $\gamma$-aminobutyric acid degradation disorder, may be associated with movement disorder, including late-onset paroxysmal dystonia responsive to vigabatrin, ${ }^{1}$ but head bobbing has not been reported. In SSADH deficiency, head bobbing may be due to increased $\gamma$-hydroxybutyrate affecting diencephalic extrapyramidal pathways via the thalamic dorsomedial nucleus. ${ }^{2}$ Other disorders associated with "yesyes" head bobbing include spasmus nutans (associated with nystagmus), rhombencephalosynapsis (cerebellar malformation), and bobble-head doll syndrome (third ventricular lesions).

Declan J. O'Rourke, MRCPI, Stephanie Ryan, FFR RCSI, FRCSI, Mary D. King, FRCPI, FRCPCH, Dublin, Ireland

Disclosure: The authors report no disclosures.

Address correspondence and reprint requests to Prof. Mary D. King, Department of Neurology, Children's University Hospital, Temple Street, Dublin 1, Ireland mary.king@cuh.ie

\section{REFERENCES}

1. Leuzzi V, Di Sabato ML, Deodato F, et al. Vigabatrin improves paroxysmal dystonia in succinic semialdehyde dehydrogenase deficiency. Neurology 2007;68:1320-1321.

2. Russo RH, Kindt GW. A neuroanatomical basis for the bobble-head doll syndrome. J Neurosurg 1974;41:720-723. 


\section{Neurology}

\section{Head bobbing due to succinic semialdehyde dehydrogenase deficiency Declan J. O'Rourke, Stephanie Ryan and Mary D. King Neurology 2010;74;2025 \\ DOI 10.1212/WNL.0b013e3181e398cf}

\section{This information is current as of June 14, 2010}

\section{Updated Information \&} Services

Supplementary Material

References

Permissions \& Licensing

Reprints including high resolution figures, can be found at: http://n.neurology.org/content/74/24/2025.full

Supplementary material can be found at: http://n.neurology.org/content/suppl/2010/06/13/74.24.2025.DC1 http://n.neurology.org/content/supp1/2010/06/13/74.24.2025.DC2

This article cites 2 articles, 1 of which you can access for free at: http://n.neurology.org/content/74/24/2025.full\#ref-list-1

Information about reproducing this article in parts (figures,tables) or in its entirety can be found online at:

http://www.neurology.org/about/about_the_journal\#permissions

Information about ordering reprints can be found online:

http://n.neurology.org/subscribers/advertise

Neurology ${ }^{\circledR}$ is the official journal of the American Academy of Neurology. Published continuously since 1951, it is now a weekly with 48 issues per year. Copyright. All rights reserved. Print ISSN: 0028-3878. Online ISSN: 1526-632X.

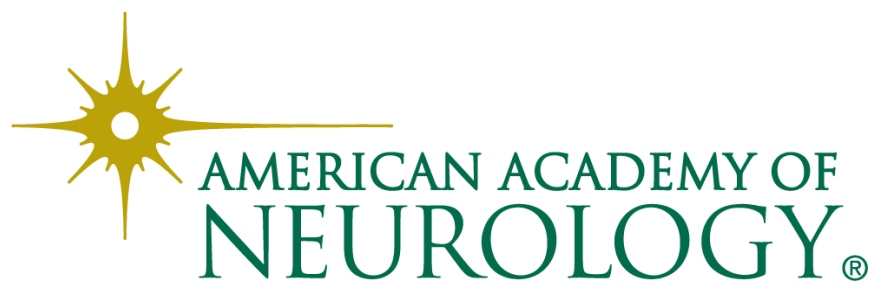

